\title{
ADOPTION OF SOYBEAN PRODUCTS AMONG WOMEN IN ONITSHA NORTH LOCAL GOVERNMENT AREA OF ANAMBRA STATE, NIGERIA
}

\author{
I.I. Nwoye ${ }^{*}$, E.G. Osegbue and M.N. Okeke \\ Received 21 August 2019, Revised 30 November 2019, Accepted 24 December 2019, Published online 31 December 2019
}

\begin{abstract}
The study examined the adoption of soybean products among women in Onitsha North Local Government Area of Anambra State, Nigeria. Specifically, it described the socioeconomic characteristics of the respondents, identified the type of soybean products available in the area, determined the source of information of the soybean products, ascertained the level of adoption of soybean products and identified the major constraints to the adoption of soybean products in the area. Purposive and simple random methods were used to select 50 respondents. Data were collected using structured questionnaire and personal interview and analyzed using descriptive statistics such as percentage, frequency distribution and mean scores. Findings show that $91.0 \%$ of the respondents were within the age range of 30-49 years, while the mean age of the farmers was 45.43 years. Extension agents (90.0\%) and friends/relatives (80.0\%) were the major source of information. Based on the level of adoption of soybean products, the farmers' adopted only five soybean products, which included soymilk, soybean cake, soybean oil, soybean nut and soy flour. The major constraints against adoption of soybean product were poor extension service to assist farmers $(\overline{\mathrm{x}}=3.7)$, lack of awareness of the soybean products $(\overline{\mathrm{x}}=3.3)$ and lack of capital $(\overline{\mathrm{x}}=3.3)$. In line with the findings, the study therefore recommends that extension agent needs to re-package and dynamically disseminate information, educate and re-educate farmers on several health benefit of soybean use in order to upgrade farmers' awareness and subsequently their adoption.
\end{abstract}

Keywords: Adoption, Soybean Products, Women, Nigeria.

Dept. of Agricultural Economics \& Extension, Chukwuemeka Odumegwu Ojukwu University, Igbariam Campus, Nigeria

*Corresponding author's email: ifeanyichukwu.nwoye@gmail.com (I.I. Nwoye)

Cite this article as: Nwoye, I.I., Osegbue,E.G. and Okeke. M.N. 2019. Adoption of soybean products among women in onitsha north local government area of Anambra state, Nigeria. Int. J. Agril. Res. Innov. Tech. 9(2): 30-34. DOI: $10.3329 /$ ijarit.v9i2.45407.

\section{Introduction}

Adequate food and proper nutrition are the basic requirements for economic development, since an underfed nation is an underproductive nation (FAO, 2017).Specifically, available statistics shows that recommended minimum per capita daily protein intake is $53.8 \mathrm{~g}(\mathrm{FAO}, 2017)$, but the estimated per capita daily protein intake is $45.4 \mathrm{~g}$ (Iyangbe and Orewa 2009).However, it is pathetic that inadequate protein in diet appears to be the greatest nutritional problem facing Nigerians today. This is because most sources of animal protein are expensive and only few people can afford enough of them in the diet (Fabiyi, 2015). It is worthy to note that when needs to alleviate poverty, malnutrition, and to improve the welfare of poor people are considered, issues relating to high quality protein food and greater income opportunity are of paramount importance. Shang and Chaplot (2017) observed that food rich in proteins provide a source of energy as well as the essential amino acids for growth and maintenance of human body. In addition, many food proteins exhibit specific biological activities that can influence human health and prevent diseases. In this regard, soybean has a great role to play because of its health benefits and low cost of purchase.

Soybean (Glycine $\max$ L.) is number one of the world import list of agricultural products (legume crop) based on value $(\mathrm{FAO}, 2013)$ indicating that it is one of the agricultural product most traded and consumed globally as it is an alternative protein source to the rural families and can be utilized at home in various forms. Nigeria is the largest producer of soybean in sub-Saharan Africa (SSA), followed by South Africa (Dalia et al., 2018) and its major producing states in Nigeria are Kaduna, Niger, Kebbi, Nasarawa, Kwara, Oyo, Jigawa, Taraba, Borno, Benue, Bauchi, Lagos, Sokoto, Plateau, Zamfara and Abuja FCT. Soybean cultivation in Nigeria has expanded 
because of its nutritive and economic importance and diverse domestic usage. Recently, it is found to be an industrially important crop used as anticorrosion agent, core oil, and bio-fuel due to less or no nitrogen element in the oil, and as disinfectant, in pesticides, printing inks, paints, adhesives, antibiotics and cosmetics (Ngalamu et al., 2012). According to Samuel and Wondaferahu (2015), dry soybean contain $36 \%$ protein, $19 \%$ oil, $35 \%$ carbohydrate $(17 \%$ of which dietary fiber), $5 \%$ minerals and several other components including vitamins. The most important domestic processing forms are dadawa, soymilk, soy ogi and soy cheese (wara). The soy-based products produced by commercial processors are soy oil, soy cake and meal, infant foods, instant foods, soy flour, soy gum and flax. The infant and instant foods industries also utilize the bean in producing soy flour, baby foods, breakfast foods, snacks and other confectioneries (Amusat and Ademola, 2013).

Malnutrition, particularly protein deficiency, is prevalent in many parts of Africa as animal protein is too expensive for most populations. Many leguminous crops provide some protein, but soybean is the only available crop that provides an inexpensive and high quality source of protein comparable to meat, poultry and eggs. Dugje et al. (2009) noted that rapid growth in the poultry sector in the past five years has also increased demand for soybean meal in Nigeria. It is believed that soybean production will increase as more farmers become aware of the potential of the crop, not only for cash/food but also for soil fertility improvement. However, despite the huge benefits and good environmental condition, soybean production remains limited in Onitsha Local Government Area notwithstanding the technological advancements that have modernized food production; processing and distribution, hunger and malnutrition persist among Nigerians (Fabiyi, 2015). More so, Fitsum (2016), noted that household size, land holding, number of livestock owned by the household head, extension contact and age of the household head are the variables, which were found to affect the level of adoption of soybean positively and significantly. It is against this background that this study was conducted to determine the adoption of soybeans products among women in Onitsha North Local Government Area of Anambra State. Specifically, the study sought to:

i. describe the socio-economic characteristic of the respondents;

ii. identify the types of soybean products available in the study area;

iii. determine the farmer's source of information;

iv. ascertain the level of adoption of soybean products in the area and;

v. identify the major constraints to the adoption of soybean products in the area.

\section{Methodology}

The study was carried out in Onitsha North Local Government Area of Anambra State, Nigeria. Onitsha North Local Government Area is one of the twenty-one (21) local government areas that make up Anambra State. It is located within longitude $6.7889^{\circ} \mathrm{E}$ and latitude $6.1589^{\circ} \mathrm{N}$ with an estimated population of 125,918 , with 61,588 males and 64,330 females (NPC, 2006).The local government area is bounded to the north by Anambra East and Anambra West local government areas, to the north-east by Oyi local government area, to the east by Idemili North local government area, to the south by Onitsha South and Idemili South local government areas, and to the west by the River Niger. All the rural women in Onitsha North constitute the population for the study. There are four Agricultural zones in Anambra state, namely: Onitsha zone, Awka zone, Aguata zone and Otuocha zone. Onitsha north Local Government as a block under study has ten (10) circles (Umudei, Obikporo, Umuasele, Ogbeoza, Odoje, Ogbeabo, Umuaroli, Ogbeodogwu, Isiokwe and Iyiawu). In stage one, out of the 10 circles, five were randomly selected, while in stage two; two (2) sub-circles were randomly selected from each of the five (5) circles, giving 10 sub-circles. Finally, five respondents were randomly selected from each sub-circle. This gave 50 respondents, which constituted the sample size for the study. Data for the study were collected from both primary and secondary sources. Structured interview schedule was utilized in gathering primary data. Descriptive statistics - frequency, mean score and percentages were used to analyze data collected.

\section{Results and Discussion}

\section{Socioeconomic characteristics of the respondents}

The socioeconomic variables in Table 1 , indicates that majority (91.0\%) of the respondents were within the age range of 30-49 years with mean age of 45.43 years. This implies that majority of the respondents are still within their active age. Marital status of the respondents shows that $74.7 \%$ of the respondents were married, whereas, $13.6 \%$ and $11.7 \%$ were single and widowed, respectively. The results also reveal that $17.0 \%$ of the respondents did not have any form of formal education, while $31.0 \%, 44.0 \%$ and $8.0 \%$ possessed primary, secondary and tertiary education, respectively. This is an indication of high literacy level among the respondents since most of them had one form of educational background or the other. Thus, it is likely to assist them in understanding the relevance of any agricultural products and facilitating the acceptance of such innovation for increase in productivity. Also in Table 1, majority (63.4\%) of the respondents had household size of 5-8 persons; $25.6 \%$ had 1-4 and 11.0\% had household 
size of 9-12 persons. The mean household size was 6.05 persons. This result means availability of family labour for the execution of farming activities at cheaper rate to the farmers. The results further reveal that $80.0 \%$ of the farmers belonged to cooperative society, while $20.0 \%$ did not belong to any co-operative society. This implies that respondents who belong to cooperative society have better chances of being exposed to soybean products and as such, increase the possibility of adopting such

Table 1. Socioeconomic distribution of respondents. products. In addition, it is pertinent to note that long exposure to new technology increases farmer's skills thus reducing the risk of failure associated with the adoption of the soybean products. This can facilitate the adoption of soybean products. On production status, the result of the analysis reveals that $88.4 \%$ of the farmers in the study area were into full time soybean production while $11.6 \%$ are into part time production.

\begin{tabular}{|c|c|c|}
\hline Socioeconomic characteristics of the respondents & Percentage (\%) & Mean $(\bar{X})$ \\
\hline \multicolumn{3}{|l|}{ Age (years) } \\
\hline $20-29$ & 6.0 & \\
\hline $30-39$ & 51.0 & \\
\hline $40-49$ & 40.0 & 45.43 years \\
\hline $50-59$ & 3.0 & \\
\hline $60-$ above & 0.0 & \\
\hline \multicolumn{3}{|l|}{ Marital Status } \\
\hline Single & 13.6 & \\
\hline Married & 74.7 & \\
\hline Widowed & 11.7 & \\
\hline \multicolumn{3}{|l|}{ Educational Level } \\
\hline No formal education & 17.0 & \\
\hline Primary & 31.0 & \\
\hline Secondary & 44.0 & \\
\hline Tertiary & 8.0 & \\
\hline \multicolumn{3}{|l|}{ Household Size } \\
\hline $1-4$ & 25.6 & \\
\hline $5-8$ & 63.4 & 6.05 persons \\
\hline $9-12$ & 11.0 & \\
\hline \multicolumn{3}{|l|}{ Member of cooperative society } \\
\hline Yes & 80 & \\
\hline No & 20 & \\
\hline \multicolumn{3}{|l|}{ Production status } \\
\hline Full time & 88.4 & \\
\hline Part time & 11.6 & \\
\hline
\end{tabular}

Types of soybean products available in the study area

Table 2 presents the mean distribution per item on the available soybean products in the study area. From the result of the analysis, the readily available soybean products in the locality included soymilk (2.8), soybean powdered milk
(2.5), soybean cake (2.3), soybean meal (2.2) and soybean flour (2.0). Whereas, soybean oil (1.5) was relatively not available. This result corroborates the findings of Ugwu and Nwoke (2011).

Table 2. Mean distribution of the soybean products available.

\begin{tabular}{|lcc|}
\hline Soybean Products & Mean Score & Rank \\
\hline Soymilk (liquid) & 2.8 & $1^{\text {st }}$ \\
\hline Soybean powdered milk & 2.5 & $2^{\text {nd }}$ \\
\hline Soybean cake & 2.3 & $3^{\text {rd }}$ \\
\hline Soybean meal & 2.2 & $4^{\text {th }}$ \\
\hline Soybean flour & 2.0 & $5^{\text {th }}$ \\
\hline Soybean oil & 1.5 & $6^{\text {th }}$ \\
\hline
\end{tabular}

\section{Farmer's sources of information}

The data in Table 3 shows that the extension agents (90.0\%) and friends/relatives (80.0\%) were the major source of information. Whereas, television (30\%) radio (20\%), newspaper (20\%) and bulletin (18\%) also constitute good sources of information on adoption of new soybean products to the farmers in the study area. 
Table 3. Distribution of respondents according to source of information.

\begin{tabular}{|l|c|}
\hline Sources of information & Percentage (\%) \\
\hline Radio & 20 \\
\hline Television & 30 \\
\hline Newspaper & 20 \\
\hline Journal text books & - \\
\hline Magazines & - \\
\hline Bulletins & 18 \\
\hline Extension agents & 90 \\
\hline Friends/relatives & 80 \\
\hline
\end{tabular}

(Multiple responses were recorded)

Determination of level of adoption of soybean product by farmers

Table 4 shows the distribution of respondents based on their level of adoption of soybean products. The result indicated that the adoption 22.5. Hence, from the data below, farmers in Onitsha North Local Government Area adopted only five (5) products, they include soymilk, soybean cake, soybean oil, soybean nut and soy flour excluding soy sauce. of the soybean products had a total mean score of

Table 4. Distribution of respondents according to their level of adoption of soybean products.

\begin{tabular}{|c|c|c|c|c|c|c|c|c|}
\hline $\begin{array}{l}\text { Soybean } \\
\text { product }\end{array}$ & $\begin{array}{c}\text { (1) } \\
\text { Aware }\end{array}$ & $\begin{array}{c}\text { (2) } \\
\text { Interest }\end{array}$ & $\begin{array}{c}\text { (3) } \\
\text { Evaluation }\end{array}$ & $\begin{array}{l}\text { (4) } \\
\text { Trail }\end{array}$ & $\begin{array}{c}\text { (5) } \\
\text { Adoption }\end{array}$ & $\begin{array}{c}\text { Total } \\
\text { Adoption }\end{array}$ & $\begin{array}{l}\text { Adoption } \\
\text { Mean }\end{array}$ & Rank \\
\hline Soy flour & 15 & 8 & 6 & 20 & 120 & 169 & 3.4 & $4^{\text {th }}$ \\
\hline Soy bean cake & 0 & 4 & 18 & 48 & 150 & 220 & 4.4 & $1^{\text {st }}$ \\
\hline Soy milk/ yoghurt & 1 & 4 & 9 & 64 & 140 & 218 & 4.4 & $1^{\text {st }}$ \\
\hline Soybean oil & 5 & 4 & 21 & 60 & 105 & 195 & 3.9 & $2^{\text {nd }}$ \\
\hline Soybean nut & 10 & 8 & 15 & 32 & 115 & 180 & 3.6 & $3^{\text {rd }}$ \\
\hline Soy sauce & 20 & 4 & 24 & 24 & 70 & 142 & 2.8 & $5^{\text {th }}$ \\
\hline Mean score & & & & & & & 22.5 & \\
\hline
\end{tabular}

(Multiple responses were recorded)

\section{Constraints to adoption of soybean products}

Data in Table 5 shows constraints to the adoption of soybean products in the study area. The most serious constraints were; poor extension service to assist farmers $(\bar{x}=3.7)$, lack of awareness to technology $(\bar{x}=3 \cdot 3)$ and lack of capital $(\bar{x}=3 \cdot 3)$. Followed by high cost of agricultural technology $(\bar{x}=2.9)$, non-availability of new technology $(\bar{x}=2.9)$, illiteracy $(\bar{x}=2.9)$, lack of use inoculants $(\bar{x}=2.8)$, inadequate market for farm product $(\bar{x}=2.6)$ andlack of good variety $(\bar{x}=2.5)$. Whereas, shortage of labour $(\bar{x}=2.0)$, high rate spoilage $(\bar{x}=1.7)$ and poor germination $(\bar{x}=1.5)$ were considered not to have a serious effect on the farmers.

Table 5. Distribution of respondents according to constraints militating against adoption of soybean product in the study area.

\begin{tabular}{|l|c|}
\hline Constraints & Mean score \\
\hline High cost of agricultural technology & 2.9 \\
\hline Non availability of new technology & 2.9 \\
\hline Lack of awareness of technology & 3.3 \\
\hline Poor extension services to assist farmers & 3.7 \\
\hline Illiteracy & 2.9 \\
\hline Lack of use inoculants & 2.8 \\
\hline Lack of capital & 3.3 \\
\hline Shortage of labour & 2.0 \\
\hline Insect Pest attack & 3.2 \\
\hline Poor germination & 1.5 \\
\hline Inadequate market for farm product & 2.6 \\
\hline Lack of good variety & 2.5 \\
\hline High rate spoilage & 1.7 \\
\hline
\end{tabular}




\section{Conclusion and Recommendations}

The study has shown that famers in Onitsha North Local Government Area of Anambra State, Nigeria have adopted to an extent the use of soybean products due to its nutritional value. However, poor agricultural extension services to farmers, lack of awareness to technology and lack of capital were the most constrained factors identified militating against the adoption of soybean products in the area and this tends to slow down the adoption rates. Extension personnel need to sit up to the desire of the farmer's towards the expected changes. It is worthy to note that choice of teaching methods plays a vital role in dissemination of specific information about soybean product, which in turn will influence the farmers desire to adopt to the products. Hence, public and nongovernmental organizations should promote publicity on importance of adequate nutrition in relation to soybean potentials. More so, to upgrade farmer's awareness and change their negative perception, extension agents need to repackage and dynamically disseminate information, educate and re-educate farmers on several health benefit of soybean use.

\section{References}

Amusat, A.S. and Ademola, A.O. 2013. Utilization of soybean in Oniyo community of Oyo State, Nigeria. Global J. Sci. Front. Res. Agric. Vet. 13(7): 8-14.

Dalia, M.K., Seifeldin, E.I., Enoch, S. and Tianfu, H. 2018. History, current status and prospects of soybean production and research in Sub-Sahara Africa. The Crop J. 6(3): 226-235.

Dugje, I.Y., Omoigui, L.O., Ekeleme, F., Bandyopadhyay, R., Lava-Kumar, P. and Kamara, A.Y. 2009. Farmers' guide to soybean production in Northern Nigeria. International Institute of Tropical Agriculture (IITA), Ibadan, Nigeria. 21p.
Fabiyi, E.F. 2015. Adoption of improved soybean technologies in processing and utilization as supplement with local foods in Bauchi Local Government Area of Bauchi State, Nigeria. American J. Expt. Agric. 6(4): 223-230.

FAO. 2013. FAOSTAT. Food and Agriculture Organization of the United Nations; Rome, Italy. Available at http://faostat.fao.org.

FAO. 2017. The state of food security and nutrition in the world. Food and Agriculture Organization of the United Nations; Rome, Italy. Retrieved from www.fao.org/3/a17695e.pdf.

Fitsum, M. 2016. Analysis of the factors affecting adoption of soybean production technology in Pawe district, Metekele zone of Benshangul Gumuz Regional State, Ethiopia. Polish Sci. J. Data. 53(3): 122-137.

Iyangbe, C.O. and Orewa, S.I. 2009.Determinants of daily protein intake among rural and lowincome urban households in Nigeria. American-Eurasian J. Sci. Res. 4(4): 290301.

Ngalamu, T., Meseka, S. and Ashraf, M. 2012. Performance of soybean (Glycine max L. Merrill) genotypes under different planting dates in Sennav State of the Sudan. J. Appl. Biosci. 49(1): 3363-3370.

NPC. 2006. National Population Census: National Population Commission, Abuja Nigeria. NPC Publication.

Samuel, D. and Wondaferahu, M.D. 2015. Determinants of adoption of soybean and its impact on the livelihood of smallholder farmers in Jimma zone. Zenith Int. J. Multidisc. Res. 5(4): 118-138.

Shang, N.S. and Chaplot, J.W. 2017. 12 - Food protein for health and nutrition. Woodhead Publishing Series in Food Science, Technology and Nutrition. University of Alberta, Edmonton, AB, Canada. pp. 301336. DOI: 10.1016/B978-0-08-100722-8.000139.

Ugwu, D.S. and Nwoke, U.M. 2011. Assessment of soybean products acceptability and consumption in Orumba North Local Government Area of Anambra State, Nigeria. Int. Res. J. Agril. Sci. Soil Sci. 1(8): 314-325. 